\title{
The Role of Novel Pasteurization Approaches on Altering Functional Properties of Egg Proteins ${ }^{\#}$
}

\author{
Hülya Serpil Kavuşan",a, Meltem Serdaroğlu',b,* \\ ${ }^{1}$ Food Engineering Department, Engineering Faculty, Ege University, 35410/Bornova/Izmir, Turkey
} * Corresponding author

\begin{tabular}{|c|c|}
\hline A R T I C L E I N F O & B S T R A C T \\
\hline $\begin{array}{l}\text { Keywords: } \\
\text { Egg } \\
\text { Egg products } \\
\text { Protein functionality } \\
\text { Novel pasteurization techniques } \\
\text { Foaming }\end{array}$ & $\begin{array}{l}\text { Eggs are important components of the human diet due to their low cost, high protein content and } \\
\text { protein related technological features. High digestibility of egg proteins makes it possible to } \\
\text { consume alone in the assay of nutritive values. Binding, emulsifying, foaming, gelling, and } \\
\text { thickening properties of egg proteins provide an opportunity to use egg in various food products as } \\
\text { an ingredient. Therefore, the consumption of egg is increasing with each passing day, however, } \\
\text { Salmonella enterica serovar Enteritidis and Salmonella Typhimirum infections have been reported } \\
\text { to be egg-born. These serious infections are originated from direct consumption of eggs or } \\
\text { unpasteurized food products in which the egg yolk/albumen is added to the formulations such as } \\
\text { mayonnaise, salad dressings or merengues. In order to prevent these infections, aforementioned } \\
\text { microorganisms must be eliminated from the environment by pasteurization. Commercial } \\
\text { pasteurization process is applied with hot water or vapor. Commercial processes include high } \\
\text { temperature/short time or low temperature/long-time pasteurization. Although heat treatment is } \\
\text { considered the most reliable method in terms of microbiological safety, high temperature and/or long } \\
\text { time applications may have adverse effects on functional and nutritional properties of egg proteins. } \\
\text { To ensure the microbiological safety of products without sacrificing technological or nutritional } \\
\text { properties, researches have been centered upon innovative techniques such as irradiation, pulsed } \\
\text { electric field, high hydrostatic pressure, and radiofrequency applications. This review is aimed to } \\
\text { bring out the amendments occurred in the egg protein structures in consequence of aforementioned } \\
\text { pasteurization methods. }\end{array}$ \\
\hline
\end{tabular}

hulyaserpilkavusan94@gmail.com (i) https://orcid.org/0000-0003-2928-8020

b@meltem.serdaroglu@hotmail.com

(D) https://orcid.org/0000-0003-1589-971X

\section{Introduction}

A whole egg consists of 8-11\% shell, 56-61\% egg white and $27-32 \%$ egg yolk. Eggs comprise of $64 \%$ egg white and $36 \%$ egg yolk in the absence of shell. Egg yolk provides most of the essential amino acids, important vitamins, folate and some micronutrients including choline while egg white contains ovalbumin, ovomucine, ovotransferrin, lysozyme, and globulin that are responsible for technological properties of egg-based products. Considering these reasons use of egg became a requirement for young or elder people diet and food product formulations (Kusum et al., 2018). Functional properties of egg proteins in foods can be sorted as binding, gelling, emulsifying, clarifying and foaming in meat loafs, custards, salad dressing, broths and angel cakes respectively (Stadelman et al., 2017). Despite the positive effects of egg proteins on health and technology, contamination of egg and eggshell through processing and nutritional composition is a major problem (Whiley and
Ross, 2015). S. enterica serotypes Typhimurium and Enteritidis are the most common microorganisms responsible for infections. Since some products added egg did not heat-treated, there might be an egg-related foodborne salmonellosis risk depending on microbial quality of egg (Gantois et al., 2009; Moffat and Musto, 2013). According to the Centers for Diseases Control and Prevention reported total 53 egg born Salmonella infections with high fever, vomiting, diarrhea and headache symptoms from 2016 to 2018 . Even though none of the cases eventuated with death, the need for pasteurization of the egg used as raw material has emerged (CDC, 2016; CDC, 2018). Liquid egg white, egg yolk, and shell egg require $56.7^{\circ} \mathrm{C} / 3.5 \mathrm{~min} ., 61.1^{\circ} \mathrm{C} / 3.5 \mathrm{~min}$, and $57^{\circ} \mathrm{C} / 75 \mathrm{~min}$. for inactivation or inhibition of Salmonella spp. (Hou et al., 1996; FDA, 2000). However application of such a high temperature or long-time induces deterioration of tertiary structure of globulins irreversibly. 
As a result of this effect, proteins loss their solubility and coagulate. Foaming properties is negatively affected temperatures between $54-60^{\circ} \mathrm{C}$ as well as texture and taste. These kinds of changes are not preferred in food matrices generally (Cunningham, 1995; Campbells et al., 2003; Akkouche et al., 2012; Uysal et al., 2017).

Various novel pasteurization techniques have been demanded recently to eliminate the disadvantages triggered by heat treatment and also to ensure the microbiological safety of the products. Irradiation, pulsed electric field, ultrasound, high hydrostatic pressure and radiofrequency are some non-conventional applications that allow avoiding high temperatures in novel pasteurization techniques (Marco-Moles et al., 2011; Singh and Ramaswanay, 2013; Uygun-Sarıbay et al., 2017; Sheng et al., 2018). In this review, it was aimed to summarize the changes in egg proteins functionality by new pasteurization techniques.

\section{The effects of novel pasteurization techniques on the egg proteins quality}

Heat pasteurization is applied to eggs in order to guarantee the microbiological safety; however, heat processing should be controlled in case of the effect on the egg protein quality. For instance, normally, electrostatic forces lead to ovomucin-lysozyme interactions in egg white. This interaction exhibits reversible characteristics and has no adverse effect on the functional properties of egg white. However, application of pasteurization induces the formation of stable, rigid and insoluble complex. This complex lead to observe undesirable changes in foaming attributes such as more whipping time is required to ensure the equivalent foaming properties as much as fresh egg white (Garibaldi et al., 1968). Further changes in foaming ability may be associated with loss of conalbumins ability to foam correspondingly, cakes formulated with pasteurized eggs illustrated harder, sticky texture and lower volume (Hatta et al., 1996; Singh et al, 2019; Uysal et al., 2019).

Another important functional property of the egg which is affected by temperature is emulsification capacity provided by egg yolk. Due to the interactions of small fragments of livetins which unfolded more than optimum concentration with the effect of heat, generation of thick emulsion is observed in mayonnaises formulated with heattreated $\left(68^{\circ} \mathrm{C}\right)$ eggs more than 7 minutes (Guilmineau and Kulozik, 2007).

Also, the color of eggs is a significant characteristic that is affected from thermal treatments as a result of 3dimensional gel structure formed and denaturation of proteins when the egg proteins meet with the heat (Min et al., 2012).

Considering the all the changes provoked by heat researches directed to new alternatives less harmful methods such as irradiation, pulsed electric field (PEF), Ultrasound, High hydrostatic pressure (HHP) and radiofrequency (RF) applications.

Irradiation is a process that can inactivate Salmonella, Escherichia coli, Listeria from the eggshells in the absence of internal or external heat (Farkas and Mohacsi-Farkas, 2011). Irradiation can be applied to egg and egg products without changing the sensory or functional properties up to 3 kGy (Bakalinov et al., 2008). Better foaming capacity and more stable viscosity are provided by irradiated egg white proteins than heat-treated egg white proteins (Min et al., 2005), yet some studies also indicated that oxidative changes as a result of irradiation can depress the foaming properties (Arvanitoyannis, 2011). Irradiation causes conformational changes in the egg white proteins from $\alpha$ helix to disordered structure and intermolecular $\beta$-sheet content was decreased as a result of irradiation (UygunSaribay et al., 2017).

In a study carried out by Song et al. (2009), it was investigated that as the dose of irradiation increased, the foaming capacity of egg white is improved and same authors revealed that angel cakes formulated with $2 \mathrm{kGy}$ irradiated egg white had the highest volume and height. Also, textural properties of angel cakes improved with the use of irradiated egg white. Increased foaming capacity could be associated with increased surface hydrophobicity and changes in $\alpha$-helix structure. Despite the positive effects of irradiation, protein and lipid oxidation are under concern (Liu et al., 2009). Other researches regarding the effects of irradiation on the properties of egg proteins are given in Table 1.

Table 1 Researches focus the effects of irradiation applications on the properties of egg proteins

\begin{tabular}{|c|c|c|c|}
\hline $\begin{array}{c}\text { Dose- } \\
\text { application }\end{array}$ & Product & Results & References \\
\hline $\begin{array}{l}0,2,5,10 \mathrm{kGy}- \\
\text { Irradiation }\end{array}$ & $\begin{array}{l}\text { Shell egg (egg } \\
\text { white analysed) }\end{array}$ & $\begin{array}{ll}\text { - } & \text { Similar foaming capacity and stability }(2.5 \mathrm{kGy}) \\
\text { - } & \text { Deteriorated color parameter (protein denaturation) } \\
\text { - } & \text { Generation of sulfur-containing volatiles }\end{array}$ & $\begin{array}{l}\text { Min et al., } \\
2012\end{array}$ \\
\hline $\begin{array}{l}0,1,2,3 \mathrm{kGy} \\
\text { Irradiation }\end{array}$ & Egg white & $\begin{array}{l}\text { - Increased foam capacity, however, decreased foam stability } \\
\text { - Decreased viscosity (separation of o glikocid from } \\
\text { ovomucin) }\end{array}$ & $\begin{array}{l}\text { Uygun } \\
\text { Sarıbay and } \\
\text { Köseoğlu, } \\
2012\end{array}$ \\
\hline $\begin{array}{l}0,1,2,3 \mathrm{kGy} \\
\text { Irradiation }\end{array}$ & Egg yolk & - Loss of zeaxanthin and lutein (due to free radicals) & $\begin{array}{l}\text { Uygun } \\
\text { Saribay et al., } \\
2014 \\
\end{array}$ \\
\hline $\begin{array}{l}0,1,2,3 \mathrm{kGy} \\
\text { Irradiation }\end{array}$ & Egg white & $\begin{array}{l}\text { - Decreased viscosity } \\
\text { - Decreased intermolecular } \beta \text { sheet content } \alpha \text {-helix to } \\
\text { disordered structure }\end{array}$ & $\begin{array}{l}\text { Uygun } \\
\text { Saribay et al., } \\
2017 \\
\end{array}$ \\
\hline
\end{tabular}




\begin{tabular}{|c|} 
No protein coagulation and lowered aggregation of proteins \\
\hline No noticable change in protein functionality \\
\hline \begin{tabular}{c} 
Lysozme inactivation (higher electrostatic fields) (loss of $\alpha$ helix structure) \\
\hline $35 \mathrm{kV} / 1200 \mu$ s induced the unfolding of tertiery structure, thus cleavaging of disulfide bonds \\
observed.
\end{tabular} \\
\hline Fpplication of PEF more than $400 \mu \mathrm{s}(25 \mathrm{kV}$ ) caused generation of insoluble lysozme, ovalbumin \\
and ovotransferrin aggerates. \\
Noaming ability as much as raw egg (up to $32 \mathrm{kV})$ \\
\hline Better gel stability (unfolding of secondary structure) \\
\hline Increased emulsion capacity (partial unfolding of proteins) \\
\hline
\end{tabular}

Figure 1 Changes in functional properties of egg affected from PEF treatment (Zhao et al., 2009; Marco-Mol'es et al. 2011; Monfort et al., 2012; Wu et al., 2014; Liu et al., 2017)

PEF is a suitable pasteurization application for liquid food, and its working principles can be explained as applying external electrical fields for a short time (Yogesh, 2016). When the PEF and thermal treatment is compared, it can be stated that while heat treatment cause and opaque appearance due to thermal coagulation of proteins, PEF did not change the color of egg white. Also up to $32 \mathrm{kV} / \mathrm{cm}$ PEF application exhibit foaming capacity as good as fresh egg white; however, after $37 \mathrm{kV} / \mathrm{cm}$ protein granules denature and degrade so, foaming capacity is affected negatively (Marco-Moles et al. 2011). Other changes in the functional properties of egg proteins affected by PEF treatment are given in Figure 1. Wu et al., (2015) reported that insoluble aggregates formed by thermal treatment contained ovotransferrin, lysozyme, and ovalbumin. Solubility of proteins is more affected by heat treatment than PEF. Electric field did not change the turbidity however, as the application time is increased turbidity is also increased due to interaction between protein molecules (Wu et al., 2015). Structure and function of lysozyme were not decreased by the action of PEF (35 $\mathrm{kV} / \mathrm{cm}$ for $300 \mu \mathrm{s}$ in sodium phosphate buffer) (Zhao and Yang, 2008).

In liquid whole eggs, $25 \mathrm{kV} / \mathrm{cm}, 105 \mu \mathrm{s}$ ve $35 \mathrm{kV} / \mathrm{cm}$, $45 \mu$ s PEF application only decreased $3 \operatorname{logs}$ of Salmonella enteritidis ve Salmonella senftenberg counts (Monfort et al., 2010); however, using PEF with heat and/or additives (lowering the surface tension) enhanced the foaming and emulsion ability of eggs, while loss of proteins were decreasing (Monfort et al., 2012; Espina et al., 2014).

HHP technology which is applying pressures to the product between 100 and $1000 \mathrm{MPa}$ has drawn attention from food industry due to the opportunity of low or moderate temperatures application during the process in order to eliminate the microorganisms without affecting the nutritional quality of foods (Koutchma, 2014; Naderi et al., 2017). Secondary structure of proteins is affected by high pressures, while tertiary and quaternary structure can be affected above $100 \mathrm{MPa}$. Since protein functionalities are provided by tertiary structure, high-pressure treatment brings about some changes in the quality of proteins (Tewari and Juneja, 2008). High-pressure treatment provokes proteins denaturation and coagulation through pressure effect (Andrassy et al., 2006). However, effects of pressure on the proteins functional properties are changeable, for instance Van Der Plancken, et al. (2007) observed that foaming stability and capacity is improved through the exposure of sulfhydryl groups by the effect of high pressures as 500-700 Mpa while another study showed that $100-500 \mathrm{MPa}$ decreased the solubility, emulsifying activity, free sulfhydryl content and surface hydrophobicity of egg yolk proteins (Yan et al., 2010). In another study, it was observed that high pressure coagulated the egg whites, also increasing pressure and application time resulted gelation of proteins like egg patties. Also pressure increased the viscosity of egg yolks (Singh and Ramaswamy, 2013). Finally, high pressure can improve the foaming properties; however, it can also lower the emulsion capacity compared to heat treatment (Monfort et al.., 2012). The foam density is positively affected by the high-pressure process; however, extensive unfoldings in proteins due to the pressure can also cause a decrease in foam stability (Singh and Ramaswamy, 2015). The changes in proteins reported by other researchers as a result of HHP are presented in Table 2.

In HHP and high intensity ultrasound (HIU) methods, foaming properties of albumen which are based on ovomucin network degradation, protein unfolding, and aggregation are affected. Under HHP and HIU treatments, ovomucin degradation produces small particles with higher solubility and flexibility (Gharbi and Labbari, 2018). Disruption of ovomucin network, unfolding and recovery of disrupted ovomucin by the formation of SS bonds and aggregation of proteins increases the surface hydrophobicity or viscosity thus, foam properties enhance (Van der Plancken et al., 2007; Brand and Kulozik, 2016; Brand et al., 2016; Naderi et al., 2017). 
Table 2 Researches focus the effects of HHP application on the properties of egg proteins

\begin{tabular}{|c|c|c|c|}
\hline $\begin{array}{c}\text { Dose- } \\
\text { application }\end{array}$ & Product & Results & References \\
\hline $\begin{array}{l}0-500 \mathrm{MPa} \\
0,20 \mathrm{~min} . \\
\text { HHP }\end{array}$ & Liquid whole egg & $\begin{array}{ll}\text { - } & \text { Maximum foaming capacity (350 MPa) (protein } \\
\text { aggregation up to a specific point) } \\
\text { - } \quad \text { Generation of sulfhydryl groups } \\
\text { - } \quad \text { Increased hydrophobicity- foaming capacity } \\
\end{array}$ & $\begin{array}{l}\text { Yang et al., } \\
2009\end{array}$ \\
\hline $\begin{array}{l}100 \mathrm{MPa} \\
1,3,5 \mathrm{~min} . \\
\mathrm{HHP}\end{array}$ & Liquid whole egg & $\begin{array}{l}\text { - Lower viscosity compared to heat-treated samples } \\
\text { - Increased foaming capacity (unfolding of sulphydryl } \\
\text { groups) }\end{array}$ & $\begin{array}{l}\text { Patrignani et } \\
\text { al., } 2013\end{array}$ \\
\hline $\begin{array}{l}600-900 \\
\text { MPa }(0-15 \\
\min ) \text { HHP }\end{array}$ & Liquid egg white & $\begin{array}{l}\text { - } \quad \text { Pressure-induced gels were soft and highly elastic } \\
\text { - } \quad \text { Full set egg gels with improved physicochemical } \\
\text { characteristics and without any cooked flavors. }\end{array}$ & $\begin{array}{l}\text { Singh and } \\
\text { Ramaswamy } \\
2013\end{array}$ \\
\hline $\begin{array}{l}400,600-800 \\
\text { MPa HHP }\end{array}$ & Egg white & $\begin{array}{l}\text { - Increase its pepsin digestibility at } 800 \mathrm{MPa} \text { to a greater } \\
\text { extent than did the thermal treatment at } 95{ }^{\circ} \mathrm{C} \text {. } \\
\text { - Increased protein digestibility } \\
\text { - } \quad \text { Less potential egg born food allergy due to increased } \\
\text { pepsin digestibility. }\end{array}$ & $\begin{array}{l}\text { Hoppe et al., } \\
2013\end{array}$ \\
\hline $\begin{array}{l}350-550 \mathrm{MPa} \\
5-15 \text { min } \\
\text { HHP }\end{array}$ & $\begin{array}{l}\text { Liquid whole egg } \\
\text { Liquid egg white }\end{array}$ & $\begin{array}{l}\text { The highest level of pressure treatment (550 MPa for } 15 \\
\text { min) was sufficient to cause complete gelatinization } \\
\text { Egg yolk to turn brighter yellow, and egg white to } \\
\text { become translucent and white in color. } \\
\text { The optimum values of color, viscosity, viscoelasticity } \\
\text { and foamingwere found at around } 550 \mathrm{MPa} \text { pressure } \\
\text { treatment for } 5 \mathrm{~min}\end{array}$ & $\begin{array}{l}\text { Singh and } \\
\text { Ramasawamy, } \\
2015\end{array}$ \\
\hline $\begin{array}{l}400 \mathrm{MPa} \\
600 \mathrm{~s} \mathrm{HHP}\end{array}$ & $\begin{array}{l}\text { Liquid whole egg } \\
\text { Liquid egg yolk }\end{array}$ & $\begin{array}{ll}\text { - } & \text { Denaturation of } 40 \% \text { of egg yolk's proteins } \\
\text { - } & \text { Aggregation and separation of protein groups } \\
\text { - } & \text { Viscous egg yolk and whole egg } \\
\end{array}$ & Tóth a 2016 \\
\hline $\begin{array}{l}200-350 \\
\mathrm{MPa}(5 \mathrm{~min}) \\
\mathrm{HHP}\end{array}$ & $\begin{array}{l}\text { Liquid whole egg } \\
\text { Liquid egg white } \\
\text { Liquid egg yolk }\end{array}$ & $\begin{array}{ll}\text { - } & \text { No detectable protein denaturation } \\
\text { - } & \text { Most pressure-sensitive egg type was liquid egg white } \\
\text { - } & \text { Similar foaming ability to raw samples } \\
\text { - } & \text { No color changes between treatments } \\
\end{array}$ & $\begin{array}{l}\text { Tóth et al } \\
2017\end{array}$ \\
\hline
\end{tabular}

Table 3 Researches focus the effects of US application on the properties of egg proteins

\begin{tabular}{|c|c|c|c|}
\hline $\begin{array}{c}\text { Dose- } \\
\text { application }\end{array}$ & Product & Results & References \\
\hline $\begin{array}{l}200-300-450 \\
\text { W } 2-5 \text { min } \\
\text { US }\end{array}$ & Shell eggs & $\begin{array}{l}\text { The higher viscosity of egg yolks compared to control } \\
\text { groups at the end of the storage. } \\
\text { - } \quad \text { Higher foaming capacity compared to control samples } \\
\text { Power levels of } 300 \mathrm{~W} \text { and } 450 \mathrm{~W} \text { of ultrasound treatments } \\
\text { had improved internal quality of fresh eggs during } \\
\text { storage, but negative effect on shell strength. }\end{array}$ & $\begin{array}{c}\text { Caner and } \\
\text { Yüceer, } 2015\end{array}$ \\
\hline $\begin{array}{l}20 \mathrm{kHz}, 34- \\
36 \text { and } 45- \\
48 \mathrm{~W} / \mathrm{m} 2 \text { for } \\
20-40 \mathrm{~min} \\
\text { US }\end{array}$ & Ovalbumin & $\begin{array}{l}\text { - Increased surface hydrophobicity and decreased surface } \\
\text { net charge } \\
\text { - } \quad \text { Higher emulsion and foaming capacity } \\
\text { - } \quad \text { Increased gelation temperatures of ovalbumin }\end{array}$ & $\begin{array}{c}\text { Xiang et al., } \\
2016\end{array}$ \\
\hline $\begin{array}{l}400 \mathrm{~W} 1,4,8 \\
12 \text { ve } 16 \\
\text { min. }\end{array}$ & Liquid egg white & $\begin{array}{l}\text { - A decline in } \alpha \text {-helices and an increase of } \beta \text {-sheets. } \\
\text { - Secondary structure content is not affected by } \\
\text { ultrasonication time. }\end{array}$ & $\begin{array}{l}\text { Zhu et al., } \\
2018\end{array}$ \\
\hline $\begin{array}{l}0,75,150 \\
225 \text { and } 300 \\
\text { W } 10 \text { min. } \\
\text { US }\end{array}$ & Egg yolk & $\begin{array}{l}\text { - Increased emulsifying, foaming and gel properties, } \\
\text { however, decreased foam stability. } \\
\text { - } \quad \text { Increased free sulfhydryl content } \\
\text { - } \quad \text { Reduced the average particle size }\end{array}$ & $\begin{array}{l}\text { Xie et al., } \\
2019\end{array}$ \\
\hline $\begin{array}{l}180 \mathrm{~W} 25 \\
\min . \\
0,15,30,45,6 \\
0,75 \text { and } 50 \\
\text { day storage }\end{array}$ & Egg white & $\begin{array}{l}\text { - Increased foaming ability } \\
\text { - Highest foaming ability was found in } 60 \text { day } \\
\text { - Increased free sulfhydryl content and surface } \\
\text { hydrophobicity, thus easier adsorption to the interface. }\end{array}$ & $\begin{array}{c}\text { Chen et al., } \\
2019\end{array}$ \\
\hline
\end{tabular}


Ultrasonic (US) treatment is another non-thermal technology that could be used instead of heat pasteurization. Ultrasonic waves transmitted to the product via media. Its popularity is increasing each passing day (Yüceer and Caner, 2018). Researches regarding the ultrasound applications to egg products are given in Table 3. Ultrasonic treatment alters the functional properties of the proteins by damaging covalent bonds and disruption of large aggregates to small particles (Stefanovic et al., 2014). Foaming capacity is associated with partial protein unfolding, higher solubility, and smaller particle size. Also, ovomucin degradation with ultrasonic cavitation could decrease particle size and viscosity. Degradated ovomucin or partially unfolded proteins adsorb to interface and enhance the foaming capacity, however, foam stability is negatively affected by the reduction of viscosity (Stefanovic et al., 2017; Sheng et al., 2018; Gharbi and Labbafi, 2019). Arzeni et al., (2012) stated that ultrasonic treatment increased the emulsion stability while the dynamics of gelation and gel strength are not affected by ultrasonication. However, Ye et al., (2018) stated that gel stability is increased by $360 \mathrm{~W}$ ultrasonication process. Quite higher foaming capacity is reported after $360 \mathrm{~W}$ ultrasound process. Approximately 5 fold higher foaming ability was found in samples treated with $360 \mathrm{~W}$ ultrasound waves than control groups. Solubility of proteins is increased through application of ultrasound, these findings are also proved by small aggregate and pores in scanning electron microscopy images (Sheng et al., 2018). Ultrasound process leads changes in tertiary structure due to increments in partial unfolding of ovalbumin and free sulfhydryl groups, therefore, emulsifying and foaming abilities of ovalbumin are enhanced (Xiong et al., 2016).

Radiofrequency is another pasteurization method that may enhance the gelling properties of egg white without sacrificing the foaming capacity (Boreddy et al., 2014). Radiofrequency treatment is thought to be a method that can be applied in order to avoid the disadvantage of longtime heat treatment in shell eggs. In a study conducted by Geveke et al., (2017), shell eggs were pasteurized in a water bath with $600 \mathrm{MHz}$. As a result time of heat treatment could be reduced up to $60 \%$ by radiofrequency treatment in terms of Escherichia coli inhibition.

Geveke et al., (2018) found that using RF treatment (35 $\mathrm{W}, 6 \mathrm{~min}$.) with hot water pasteurization $\left(56.7^{\circ} \mathrm{C} 5,10\right.$ and 15 min.) provided better inactivation of Salmonella than samples only treated with $56.7^{\circ} \mathrm{C}$ for $60 \mathrm{~min}$ without affecting the albumen quality. Angel cakes formulated with eggs pasteurized with $\mathrm{RF}+56.7^{\circ} \mathrm{C} 15 \mathrm{~min}$. had better volume than samples treated with hot water for $60 \mathrm{~min}$. Better foaming stability and lower whipping time are reported with combined use of RF and hot water treatment than hot water treated samples (Yang et al., 2019).

\section{Conclusion}

Heat application to egg and egg products could meet the microbiological requirements based on the time and temperature parameters. High temperature applications or long application period lead to heat-induced changes in egg proteins that may cause loss of some functional and nutritional properties. In order to minimize these undesirable changes, researches are focused on some novel approaches such as irradiation, pulsed electric field, ultrasound, high hydrostatic pressure and radiofrequency. All novel methods had favourable effects on foaming, emulsifying, gelling properties or solubility of egg proteins depending on the parameters (time, electric field, power or etc.). Irradiation process aggregates the proteins up to a specific level, by this effect a decrement in viscosity and increment in foaming capacity are observed, however, there are some suspicious thoughts due to increment in oxidation processes.

Since pulsed electric field method does not contain heat, no colour changes are taking place, as a matter of fact unfolding of proteins triggered by electric field enhance gelling and foaming properties. Despite the positive effects, microbiological safety of eggs processed with this method is under concern, thus it is recommended that PEF should be used with mild heat treatments.

HHP treatment positively affects the functionality of proteins depending on the pressure, however, increasing pressure may destruct the functional properties. Changes observed in ovomucin as a result of ultrasound treatment increase the foaming ability. Radiofrequency is a method that should be used with heat treatment. The radiofrequency treatment has minimal change on egg proteins as a result of reduced temperature and/or time.

It can be concluded that novel techniques can replace commercially available heat treatment, however, further researches are needed to focus the microbiological and functional changes in egg-containing products (cake, merengue, etc.) when the egg in the formulation treated one of these novel methods. These studies will show whether these methods can be used as a complete heat process replacer.

\section{References}

Akkouche Z, Aissat L, Madani K. 2012. Effect of heat on egg white proteins. In International Conference on Applied Life Sciences. IntechOpen. Turkey, September 10-12. 407-413.

Andrassy E, Farkas J, Seregély Z, Dalmadi I, Tuboly E, Lebovics V. 2006. Changes of hen eggs and their components caused by non-thermal pasteurizing treatments II. Some nonmicrobiological effects of gamma irradiation or hydrostatic pressure processing on liquid egg white and egg yolk. Acta Alimentaria, 35(3): 305-318. DOI: 10.1556 /AAlim.35.2006.3.8

Arvanitoyannis IS. 2011. Irradiation of Food Commodities, Techiniques, Apparataus, Dedection, Legislation, Safety and Consumer Opinion. First edition,, Oxford, UK. Elsevier.

Arzeni C, Pérez OE, Pilosof AM. 2012. Functionality of egg white proteins as affected by high intensity ultrasound. Food Hydrocoll., 29(2): 308-316. DOI: 10.1016/j.foodhyd. 2012.03.009

Bakalinov S, Tsvetkova E, Bakalinova T, Tsvetkov T, Kaloyanov N, Grigorova S, Alxiev, V. 2008. Characterization of freezedried egg melange long stored after irradiation. Radiation Phys. Chem., 77(1): 58-63. DOI: 10.1016/j.radphyschem. 2007.02.005

Boreddy SR, Birla S, Froning G, Thippareddi H, Subbiah J. 2014. Effect of radio frequency assisted thermal processing on quality and functional properties of egg white powder. Transactions of the ASABE, 57(6): 1761-1770. DOI: 10.13031/trans.57.10781

Brand J, Kulozik U. 2016. Comparison of different mechanical methods for the modification of the egg white protein ovomucin, part B: molecular aspects. Food Bioprocess Technol., 9(7): 1210-1218. DOI: 10.1007/s11947-016-1711-4 
Brand J, Silberbauer A, Kulozik U. 2016. Comparison of different mechanical methods for the modification of the egg white protein ovomucin, part A: physical effects. Food Bioprocess Technol., 9(3): 501-510. DOI: 0.1007/s11947-015-1647-0

Campbell L, Raikos V, Euston, SR. 2003. Modification of functional properties of egg-white proteins. Food/Nahrung, 47(6): 369-376. DOI: 10.1002/food.200390084

Caner C. Yuceer M. 2015. Maintaining functional properties of shell eggs by ultrasound treatment. J. Sci. Food and Agric., 95(14): 2880-2891. DOI: $10.1002 /$ jsfa.7029

CDC, Centers for Disease Control and Prevention. 2016 Salmonella Oranienburg Infections Linked to Good Earth Egg Company Shell Eggs. https://www.cdc.gov /salmonella/oranienburg-10-16/epi.html.

CDC, Centers for Disease Control and Prevention. 2018. People infected with the outbreak strain of Salmonella Braenderup, by state of residence, as of June 13. https://www.cdc.gov /salmonella/braenderup-04-18/map.html.

Chen Y, Sheng L, Gouda M, Ma M. 2019. Impact of ultrasound treatment on the foaming and physicochemical properties of egg white during cold storage. LWT, - Food Sci. Technol. 113: 108303. DOI: 10.1016/j.lwt.2019.108303

Cunningham FE. 1995. Egg product pasteurization. Egg Sci. Technol., 4: 289-315.

Espina L, Monfort S, Álvarez I, García-Gonzalo D, Pagán R. 2014. Combination of pulsed electric fields, mild heat and essential oils as an alternative to the ultrapasteurization of liquid whole egg. Int. J. Food Microbiol., 189: 119-125.

Farkas J, Mohácsi-Farkas C. 2011. History and future of food irradiation. Trends Food Sci. Technol., 22(2-3): 121-126. DOI : 10.1016/j.tifs.2010.04.002

FDA, Food and Drug Administration. 2000. Kinetics of microbial inactivation for alternative food processing technologies. Available at: http://www.cfsan.fda.gov/ comm/ift-over.html.

Gantois I, Ducatelle R, Pasmans F, Haesebrouck F, Gast R, Humphrey TJ, Van Immerseel F. 2009. Mechanisms of egg contamination by Salmonella Enteritidis. FEMS Microbial. Rev., 33(4): 718-738. DOI: 10.1111/j.1574-6976.2008. 00161.x

Garibaldi JA, Donovan JW, Davis JG, Cimino SL. 1968. Heat Denaturation of the Ovomucin-Lysozynie Electrostatic Complex-A Source of Damage to the Whipping Properties of Pasteurized Egg White. J. Food Sci., 33(5): 514-524. DOI: 10.1111/j.1365-2621.1968.tb03666.x

Geveke DJ, Bigley AB, Brunkhorst CD, Jones DR, Tilman ED. 2018. Improvement in the radio frequency method to pasteurise shell eggs by automation and cost reduction. Int. J. Food Sci. Technol., 53(11): 2500-2508. DOI: 10.1111 /ijfs. 13843

Geveke DJ, Bigley AB, Brunkhorst CD. 2017. Pasteurization of shell eggs using radio frequency heating. J. Food Eng., 193: 53-57. DOI: 10.1016/j.jfoodeng.2016.08.009

Gharbi N, Labbafi M. 2019. Influence of treatment-induced modification of egg white proteins on foaming properties. Food Hydrocoll., 90: 72-81. DOI: 10.1016/j. foodhyd.2018.11.060

Guilmineau F, Kulozik U. 2007. Influence of a thermal treatment on the functionality of hen's egg yolk in mayonnaise. J. Food Eng., 78(2): 648-654. DOI: 10.1016/j.jfoodeng.2005.11.002

Hatta H, Ozeki M, Tsuda K. 1996. Egg yolk antibody IgY and its application. Hen Eggs: Basic and Applied Science. USA, CRC Press.

Hoppe A, Jung S, Patnaik A, Zeece MG. 2013. Effect of high pressure treatment on egg white protein digestibility and peptide products. Innov. Food Sci. Emerg. Technol., 17: 5462. DOI: $10.1016 /$ j.ifset.2012.11.003

Hou H, Singh RK, Muriana PM, Stadelman WJ. 1996. Pasteurization of intact shell eggs. Food Microbiol., 13(2): 93-101. DOI: 10.1006/fmic.1996.0012
Koutchma T. 2014. Adapting high hydrostatic pressure (HPP) for food processing operations. Academic Press.

Kusum M. 2018. A review: Chemical composition and utilization of egg. IJCS, 6(3): 3186-3189.

Liu XD, Han RX, Yun H, Jung KC, Jin DI, Lee BD, Min TS, Jo C. 2009. Effect of irradiation on foaming properties of egg white proteins. Poultry Sci., 88(11): 2435-2441. DOI: 10.3382/ps.2009-00063

Marco-Molés R, Hernando I, Quiles A, Llorca E, Pérez-Munuera I. 2011. Changes in the Microstructure and Protein Fraction of Whole Liquid Egg treated by Pulsed Electric Fields (PEF). Impacto de nuevas tecnologías de conservación sobre la estructura y los principales componentes químicos de alimentos fluidos, 67-80.

Min B, Nam KC, Jo C, Ahn DU. 2012. Irradiation of shell egg on the physicochemical and functional properties of liquid egg white. Poultry Sci., 91(10): 2649-2657. DOI: 10.3382/ps.2012-02345

Min BR, Nam KC, Lee EJ, Ko GY, Trampel DW, Ahn DU. 2005. Effect of irradiating shell eggs on quality attributes and functional properties of yolk and white. Poultry Sci., 84(11): 1791-1796. DOI: $10.1093 / \mathrm{ps} / 84.11 .1791$

Moffatt CR, Musto J. 2013. Salmonella and egg-related outbreaks. Microbiol. Australia, 34(2): 94-98.

Monfort S, Gayán E, Raso J, Condón S, Álvarez I. 2010. Evaluation of pulsed electric fields technology for liquid whole egg pasteurization. Food Microbiol., 27(7): 845-852. DOI: $10.1016 /$ j.fm.2010.05.011

Monfort, S., Ramos, S., Meneses, N., Knorr, D., Raso, J., \& Álvarez, I. (2012). Design and evaluation of a high hydrostatic pressure combined process for pasteurization of liquid whole egg. Innovative Food Science \& Emerging Technologies, 14, 1-10. DOI: 10.1016/j.ifset.2012.01.004

Naderi N, House JD, Pouliot Y, Doyen A. 2017. Effects of high hydrostatic pressure processing on hen egg compounds and egg products. Compr. Rev. Food Sci. F., 16(4): 707-720. DOI: $10.1111 / 1541-4337.12273$

Patrignani F, Vannini L, Kamdem SLS, Hernando I, MarcoMolés R, Guerzoni ME, Lanciotti R. 2013. High pressure homogenization vs heat treatment: Safety and functional properties of liquid whole egg. Food Microbiol., 36(1): 6369. DOI: $10.1016 / \mathrm{j} . \mathrm{fm} .2013 .04 .004$

Sarıbay MU, Köseoğlu T. 2012. Effect of Irradiation on Foaming Ability of Liquid Egg White (Turkish with English Abstract). GIDA/THE JOURNAL OF FOOD, 37(5).

Sheng L, Wang Y, Chen J, Zou J, Wang Q, Ma M. 2018. Influence of high-intensity ultrasound on foaming and structural properties of egg white. Food Res. Int., 108: 604610. DOI: 10.1016/j.foodres.2018.04.007

Sheng L, Wang Y, Chen J, Zou J, Wang Q. Ma M. 2018. Influence of high-intensity ultrasound on foaming and structural properties of egg white. Food Res. Int., 108: 604610. DOI: $10.1016 /$ j.foodres.2018.04.007

Singh A, Ramaswamy HS. 2015. High pressure modification of egg components: Exploration of calorimetric, structural and functional characteristics. Innov. Food Scie. Emerg., 32: 4555. DOI: $10.1016 /$ j.ifset.2015.09.010

Singh A, Geveke DJ, Jones DR, Tilman ED. 2019. Can acceptable quality angel food cakes be made using pasteurized shell eggs? The effects of mixing factors on functional properties of angel food cakes. Food Sci. Nutr., 7(3): 987-996. DOI: 10.1002/fsn3.911

Singh A, Ramaswamy H. 2013. Effect of high pressure processing on color and textural properties of eggs. J. Food Res., 2(4): 11. DOI: 10.5539/jfr.v2n4p11

Song HP, Kim B, Choe JH, Jung S, Kim KS, Kim DH, Jo C. 2009. Improvement of foaming ability of egg white product by irradiation and its application. Radiation Phys. Chem., 78(3): 217-221. DOI: 10.1016/j.radphyschem.2008.10.001 
Stadelman WJ, Newkirk D, Newby L. 2017. Egg science and technology. Fourth edition, USA, CRC Press.

Stefanović A, Jovanović J, Dojčinović M, Lević S, Žuža M, Nedović V, Knežević-Jugović Z. 2014. Impact of highintensity ultrasound probe on the functionality of egg white proteins. JHED., 6: 215-224.

Stefanović AB, Jovanović JR, Dojčinović MB, Lević SM, Nedović VA, Bugarski BM, Knežević-Jugović ZD. 2017. Effect of the controlled high-intensity ultrasound on improving functionality and structural changes of egg white proteins. Food Bioprocess Technol., 10(7): 1224-1239. DOI: 10.1007/s11947-017-1884-5

Tewari G, Juneja V. (Eds.). 2008. Advances in thermal and nonthermal food preservation. John Wiley \& Sons.

Tóth A, Németh C, Juhász R, Zeke I, Csehi B, Bényi D, Friedrich L. 2016. Effects of $\mathrm{HPH}$ processing at $400 \mathrm{MPa}$ on proteins of liquid egg products. Review on Agriculture and Rural Development, 5(1-2): 153-157.

Tóth A, Németh C, Palotás P, Surányi J, Zeke I, Csehi B Castillo L A, Friedrich L, Balla C. October, 2017. HHP treatment of liquid egg at 200-350 MPa. In Journal of Physics: Conference Series (Vol. 950, No. 4, p. 042008) IOP Publishing: : 1-6 DOI: $10.1088 / 1742-6596 / 950 / 4 / 042008$

Uygun-Sarıbay M, Ergun E, Kalaycı Y, Köseoğlu, T. 2017. The secondary structure of proteins in liquid, frozen, and dried egg-white samples: Effect of gamma irradiation treatment. Int. J. Food Prop., 20: 1195-1203. DOI: 10.1080/10942912.2016.1241263

Uygun-Sarıbay M, Ergun E, Köseoğlu T. 2014. Effect of gamma irradiation and storage on lutein and zeaxanthin in liquid, frozen and dried egg yolk samples. J. Radioanal. Nucl. Chem., 301(2): 597-605. DOI: 10.1007/s10967-014-3171-5

Uysal RS, Sumnu G, Boyaci IH. 2019. Effects of heat-treated liquid whole egg on cake batter rheology and the quality of baked cake. J. Food Process Eng., 42(2): 1-10. DOI: $10.1111 /$ jfpe. 12977

Uysal, RS, Boyacı İH, Soykut EA, Ertaş N. 2017. Effects of heat treatment parameters on liquid whole egg proteins. Food Chem., 216: 201-208. DOI: 10.1016/j.foodchem.2016.08.050

Van der Plancken I, Van Loey A, Hendrickx ME. 2007. Foaming properties of egg white proteins affected by heat or high pressure treatment. J. Food Eng., 78(4): 1410-1426. DOI: 10.1016/j.jfoodeng.2006.01.013

Van der Plancken I, Van Loey A, Hendrickx ME. 2007. Foaming properties of egg white proteins affected by heat or high pressure treatment. J. Food Eng. 78(4): 1410-1426. DOI: 10.1016/j.jfoodeng.2006.01.013

Whiley H, Ross K. 2015. Salmonella and eggs: from production to plate. Int. J. Environ. Res Public Health, 12(3): 2543-2556. DOI: $10.3390 /$ ijerph120302543
Wu L, Zhao W, Yang R, Chen X. 2014. Effects of pulsed electric fields processing on stability of egg white proteins. J. Food Eng., 139: 13-18. DOI: 10.1016/j.jfoodeng.2014.04.008

Wu L, Zhao W, Yang R, Yan W. 2015. Pulsed electric field (PEF)-induced aggregation between lysozyme, ovalbumin and ovotransferrin in multi-protein system. Food Chem., 175: 115-120. DOI: 10.1016/j.foodchem.2014.11.136

Xie Y, Wang J, Wang Y, Wu D, Liang D, Ye H, Cai Z, Ma M, Geng F. 2019. Effects of high-intensity ultrasonic (HIU) treatment on the functional properties and assemblage structure of egg yolk. Ultrasonics Sonochemistry, 104767. DOI: 10.1016/j.ultsonch.2019.104767

Xiong W, Wang Y, Zhang C, Wan J, Shah BR, Pei Y, Zhou B, Li J, Li B. 2016. High intensity ultrasound modified ovalbumin: structure, interface and gelation properties. Ultrasonics Sonochemistry, 31: 302-309. DOI: 10.1016/j.ultsonch.2016.01.014

Yan W, Qiao L, Gu X, Li J, Xu R, Wang M, Reuhs B, Yang Y. 2010. Effect of high pressure treatment on the physicochemical and functional properties of egg yolk. Eur. Food Res. Technol., 231(3): 371-377. DOI: 10.1007/s00217010-1286-7

Yang RX, Li WZ, Zhu CQ, Zhang Q. 2009. Effects of ultra-high hydrostatic pressure on foaming and physical-chemistry properties of egg white. J. Biomed. Sci. Eng., 2(08): 617-620. DOI: 10.4236/jbise.2009.28089

Yang Y, Geveke DJ, Brunkhorst CD, Sites JE, Geveke NJ, Tilman ED. 2019. Optimization of the radio frequency power, time and cooling water temperature for pasteurization of Salmonella Typhimurium in shell eggs. J. Food Eng., 247: 130-135. DOI: 10.1016/j.jfoodeng.2018.12.004

Ye Y, Gao J, Chen H, Tong P. 2018. Effect of ultrasonic processing on protein structure and gel properties of egg white. Shipin Kexue/Food Sci., 39(21): 45-52. DOI: 10.7506/spkx1002-6630-201821007

Yogesh K. 2016. Pulsed electric field processing of egg products: a review. J. Food Sci. Technol., 53(2): 934-945. DOI: 10.1007/s13197-015-2061-3

Yüceer M, Caner C. 2018. Ultrasound; A Novel and Innovative Processing Method for Egg and Egg Products Preservation. J. Chem. Biol. Pharm. Chem, 1(1): 1-3.

Zhao W, Yang R. 2008. The effect of pulsed electric fields on the inactivation and structure of lysozyme. Food Chem., 110(2): 334-343. DOI: 10.1016/j.foodchem.2008.02.008

Zhu Y, Vanga SK, Wang J, Raghavan V. 2018. Effects of Ultrasonic and Microwave Processing on Avidin Assay and Secondary Structures of Egg White Protein. Food Bioprocess Technol., 11(11): 1974-1984. DOI: 10.1007/s11947-0182158-6 